\title{
TPACK updated to measure pre-service teachers' twenty-first century skills
}

Teemu Valtonen, Erkko Sointu, Jari Kukkonen, Sini Kontkanen

University of Eastern Finland

Matthew C. Lambert

University of Nebraska-Lincoln

Kati Mäkitalo-Siegl

University of Eastern Finland

\begin{abstract}
Twenty-first century skills have attracted significant attention in recent years. Student of today and the future are expected to have the skills necessary for collaborating, problem solving, creative and innovative thinking, and the ability to take advantage of information and communication technology (ICT) applications. Teachers must be familiar with various pedagogical approaches and the appropriate ways to use ICT to support the development of their students' twenty-first century skills. The technological pedagogical content knowledge (TPACK) framework provides a theoretical model for studying the ways in which teachers use ICT in education. Still, the TPACK framework faces certain difficulties, especially concerning the instruments currently used for studying TPACK. These challenges are primarily related to the psychometric properties of the instruments and areas of pedagogical knowledge. Within this paper we introduce a new TPACK questionnaire, the TPACK-21 questionnaire which is grounded on twenty-first century skills. The TPACK-21 questionnaire is validated using confirmatory factor analysis (CFA). Results provide a six factor CFA model aligning with the TPACK theoretical framework. Also, the associations among TPACK sub-constructs, and the weak and strong areas of pre-service teachers' TPACK will be discussed.
\end{abstract}

\section{Introduction}

The development of information and communication technology (ICT) has induced major economic changes. These changes are creating new expectations for today's schools and teachers. To meet these expectations, today's students are expected to gain so-called twenty-first century skills. These skills have been defined in many existing frameworks, such as the international project Assessment and Teaching of $21^{\text {st }}$ Century Skills (ATC21S ${ }^{\text {TM }}$ ), the US-based initiative Partnership for $21^{\text {st }}$ Century Skills, Definition and Selection of Competences and the European Union's Key Competences for Lifelong Learning by Organisation for Economic Co-operation and Development (OECD) (Ananiadou \& Claro, 2009; Binkley et al., 2012; Gordon et al., 2009; P21Skills, 2013). Despite this range of definitions, all agree that students must master the following: collaboration, communication, ICT literacy, social and/or cultural competencies, creativity, critical thinking, and problem-solving (Kereluik, Mishra, Fahnoe, \& Terry, 2013; Mishra \& Kereluik, 2011; Mishra \& Mehta, 2017; Voogt, Fisser, Roblin, Tondeur, \& Braakt, 2013; Voogt \& Roblin, 2012). All the definitions emphasise the importance of ICT skills. Specifically, students must be able to use ICT as a tool in areas related to twenty-first century skills, including learning, collaborating, problem-solving, and creative and innovative thinking. In other words, ICT skills serve as the hub for twenty-first century skills.

According to Voogt et al. (2013), teachers must know various pedagogical approaches to take advantage of ICT and support the development of students' twenty-first century skills. This suggests that twenty-first century skills must be included in teacher education. There is a consensus that teachers must provide students with learning content in ways that support the students' development of twenty-first century skills (Rotherham \& Willingham, 2009). Although such skills—often labelled soft or generic skills—have been widely recognised in curriculum standards, the main emphasis in standards and assessment remains on the hard skills in language and mathematics, along with hard factual knowledge (Scardamalia, Bransford, Kozma, \& Quellmalz, 2012). The consensus among researchers in the learning sciences is that these two 
ideas are not in conflict. That is, problem-solving and social skills are not practised separately from subject knowledge (cf. Murgatroyd, 2010). Thinking skills and working skills are actually best learned together in their natural context (e.g. Rotherham \& Willingham, 2009; Silva, 2009).

Twenty-first century skills are emphasised in different countries' national educational goals. However, in terms of actual teaching practices, the role of such skills is much weaker (cf. Voogt et al., 2013). We consider pre-service teacher education to be the right place to address the challenges faced by national and international educational systems. However, there is a need to develop a framework for studying and describing pre-service teachers from the twenty-first century skills perspective. This framework should be based on theory and empirical evidence to enable the measurement and follow-up of pre-service teachers' educational paths.

In this paper, we focus on twenty-first century skills from the perspective of technological pedagogical content knowledge (TPACK), aiming to combine these frameworks. TPACK is a well-known theoretical approach among researchers studying (pre-service) teachers' use of ICT (cf. Voogt et al., 2013). TPACK can be seen as a flexible framework for various research purposes. According to Mishra, Koehler and Henriksen (2010) the TPACK framework can be used for different pedagogical approaches as well as different content areas and technologies. The TPACK framework has also been developed for twenty-first century skills (Mishra et al., 2010), and used as a framework for developing teachers' readiness toward the twenty-first century skills (Figg \& Jaipal, 2012; Koehler et al., 2011). Currently there is a need for designing a TPACK measurement instrument aligning with the twenty-first century skills. Twenty-first century skills place a strong emphasis on pedagogy, including pedagogical practices such as collaborative learning and problem-solving (Voogt \& Roblin, 2012). We assume that the TPACK framework, when aligned with the pedagogical aspects of twenty-first century skills, will provide a comprehensive framework for studying and supporting pre-service teachers' TPACK development aligning with twenty-first century skills. Thus, the aim of this article is to (1) present the TPACK framework and outline the challenges related to TPACK measurement instruments available, (2) outline ways of developing current TPACK research instruments to better consider twenty-first century skills with empirical evidence.

\section{How can the TPACK framework be developed to better match twenty-first century pedagogical needs?}

This part of the paper outlines the characteristics of the TPACK framework and measurement instruments available. The focus related to TPACK measurement instruments is specifically on pedagogical perspectives and challenges related to the psychometrics of the questionnaires.

\section{Technological pedagogical content knowledge - theoretical framework}

TPACK is a theoretical framework for describing and studying teachers' professional knowledge. According to Koehler, Mishra and Cain (2013), TPACK is the heart of good teaching and consists of three components: content, pedagogy, and technology. The TPACK framework is built on Shulman's (1986, 1987) pedagogical content knowledge (PCK) framework. PCK refers to the knowledge base needed for teaching, requiring a blend of content and pedagogical knowledge, as described below (Shulman, 1987):

- $\quad$ Content knowledge (CK): knowledge that includes central theories and concepts of topics taught. Furthermore, CK requires an understanding of the nature of the knowledge and the means of inquiry in the field (e.g. biology, mathematics etc.).

- $\quad$ Pedagogical knowledge (PK): an understanding of learning processes and the ability to control and guide the learning situation. PK is a generic form of knowledge about the cognitive, social and developmental theories of learning.

Technological pedagogical content knowledge (TPACK) adds a technological dimension to the PCK framework. TPACK implies knowledge of effective teaching with ICT applications that are suitable in terms of pedagogy and content (Koehler et al., 2013). Koehler et al. (2013) identify the following components of TPACK: 
- Technological knowledge (TK): an understanding of the possibilities and constraints of technology and the skills to utilise technology efficiently. Technology knowledge also implies an interest in following the development of new technologies.

- Technological content knowledge (TCK): an understanding of the link between content knowledge and technology and how technology and content influence and constrain one another. TCK refers to knowledge about the technologies used within the content area (e.g. biology, mathematics etc.).

- Technological pedagogical knowledge (TPK): an understanding of the nature of teaching and learning with technology and of the benefits and disadvantages of various technologies for particular pedagogical practices.

The TPACK framework is built on these elements and describes the seven areas of teacher knowledge that serve as the heart of good teaching (Koehler et al., 2013).

\section{Flexible framework - defining pedagogy}

The TPACK framework can be seen as a flexible tool for various research purposes. According to Mishra et al. (2010) the TPACK framework offers no directives concerning what pedagogical approaches are useful. This aligns with the views by Brantley-Dias and Ertmer (2013) who describe TPACK suitable for various pedagogical orientations. This same flexible feature can be seen in other areas of TPACK. TPACK has been studied in various content areas, including math (Landry, 2010), biology (Kontkanen et al., 2015), sustainable development (Sointu et al., 2016), and special education (Lyublinskaya \& Tournaki, 2014). Similarly, TPACK has been studied from the perspectives of different technologies, such as the world wide web (Lee \& Tsai, 2010), Second Life (Kontkanen et al., 2015), and social software (Valtonen, Kontkanen, Dillon, Kukkonen, \& Väisänen, 2014). This feature makes it possible to apply the TPACK framework flexibly to various areas to study topics related to ICT in various education contexts.

Currently there are several questionnaires available for measuring TPACK (Chai, Koh, \& Tsai, 2016). The focus of this article is particularly on the pedagogical aspects of TPACK questionnaires. The role of pedagogical knowledge areas (PK, PCK, TPK and TPACK) varies between questionnaires used for measuring TPACK areas. The actively used and modified instrument called the survey of preservice teachers' knowledge of teaching and technology (SPTKTT) (Schmidt et al., 2009) measures teachers' pedagogical knowledge using statements like the following:

- I know how to assess student performance in a classroom.

- I can adapt my teaching based upon what students currently understand or do not understand.

- I know how to organise and maintain classroom management.

These statements can be seen as very general-level statements when compared to another instrument and its statements developed by Koh and Chai (2011). Their areas measuring pedagogical thinking are based on Jonassen, Peck and Wilson's (1999) theory of meaningful learning, which more directly focuses on certain learning theories - that is, the pedagogical practices used by the teacher, as seen in the following:

- I am able to help my students to monitor their own learning.

- I am able to help my students to reflect on their learning strategies.

- $\quad$ I am able to plan group activities for my students.

When considering these differences from the perspective of earlier research related to pedagogical knowledge, such as research on teachers' conceptions of teaching and learning (cf. Boulton-Lewis, 2004; Kember, 1997), this topic becomes important. Kember (1997) outlines various conceptions of teaching, conceiving of two broad orientations: 1) teacher-centred/content-oriented, and 2) student-centred/learningoriented. These orientations refer to different ways of understanding teaching and learning, different pedagogical knowledge areas, and different relationships to twenty-first century skills. From the measurement instrument perspective, the challenge of the statements in the SPTKTT questionnaire (Schmidt et al., 2009) is that respondents' answers to areas related to pedagogical knowledge may be very similar, even among teachers with different teaching orientations. Respondents with different orientations toward teaching and learning may evaluate their knowledge related to assessing students and their 
knowledge related to maintaining classroom organisation in the same way. In contrast, the questionnaire by Koh and Chai (2011) focuses on areas of meaningful learning, emphasising the students' role in monitoring their own learning, collaboration, and reflective thinking.

From the perspective of twenty-first century skills, the development of the questionnaires is important. Currently there are tools, tasks, and questionnaires for assessing twenty-first century skills (Ahonen \& Kankaanranta, 2015; Honey, Fasca, Gersick, Mandinach, \& Sinha, 2005; Soh, Osman, \& Arsad, 2012). Still, the questionnaires focused on teachers' and especially on pre-service teachers' twenty-first century skills are scarce. We assume that the development of instrument measuring twenty-first century skills need to align with the direction suggested by Koh and Chai (2011). Within the questionnaire by Koh and Chai the pedagogical knowledge areas were grounded on theory of meaningful learning, that is, the pedagogical approaches emphasised were active learning, collaboration, and reflective thinking, aligning also with the twenty-first century skills. Still, the twenty-first century skills emphasise skills like collaboration, communication, creativity, problem solving, and critical thinking with a strong emphasis on the role of ICT in teaching and learning (cf. Voogt \& Roblin, 2012). These skills and aligning pedagogical practices provide the framework for designing new TPACK measurement instrument, where the areas containing pedagogical knowledge (PK, TPK, PCK, TPACK) are grounded on these skills.

\section{Measuring TPACK with questionnaires}

In addition to the role of pedagogy as a part of TPACK, there is an active investigation into how to design theory-driven, psychometrically sound questionnaires for measuring TPACK and its elements (Table 1). Schmidt et al. (2009) produced the SPTKTT questionnaire to measure the seven areas of TPACK. This instrument has been used in several studies, but it has attracted some criticism for its validation process, which was conducted separately for each area of TPACK (i.e. PK, TK, CK, TPK, PCK, and TCK) using principal component analysis (PCA) (Chai, Koh, Tsai, \& Tan, 2011). Also, another issue of SPTKTT is defined as the operationalisation of the content-related constructs of TPACK, meaning that examining several different types of content simultaneously may cause problems for the interpretation (Chai et al., 2016). In addition to the SPTKTT questionnaire itself, several studies have reported the use of instruments based on the SPTKTT. The SPTKTT has been used in its original form and further developed to address specific technologies (cf. Lee \& Tsai, 2010) and more specific pedagogical approaches (cf. Chai et al., 2011). Within these studies, the instruments' psychometric properties have been investigated with various methods, such as explorative factor analysis (EFA), including principal component analysis PCA), confirmatory factor analysis (CFA), and structural equation modelling (SEM), to test different aspects of validity and reliability.

The results of these various studies indicate a challenge in separating all seven areas of TPACK with empirical data using EFA and CFA. The study by Chai et al. (2011) reported on five out of seven elements of TPACK; TCK and PCK were not loaded as separate factors. Similarly, in research by Archambault and Barnett (2010), the only separate factor loading, as expected, was technological knowledge; the other elements were combined into three factors. In a study by Koh et al. (2010), the same kind of challenge was indicated, and only two factors were loaded that aligned with the TPACK frame: the factors for content knowledge and technological knowledge. In the development of TPACK assessment instruments, pedagogy-, content- and technology-specific questionnaires seems to replicate most strongly the original TPACK structure (e.g. Chai et al., 2011; Chai et al., 2013; Koh et al., 2013; Valtonen et al., 2015).

Despite these challenges, there are also promising studies into which the areas of TPACK have loaded in alignment with the TPACK model. In a study by Chai et al. (2011), the factor structure aligning with the TPACK framework was found for two content knowledge areas. The analysis was conducted using EFA and CFA. Koh et al. (2013) reported seven factors in their study with CFA and path modelling. However, in their study, interesting questions arose from the perspective of the direct and indirect effects of the TPACK construct on TPACK itself. Also, Chai et al. (2013) reported seven factors, but their study highlighted another aspect of cultural differences of TPACK. In the study by Valtonen et al. (2015), seven elements of TPACK loaded in alignment with the TPACK framework. The analysis was conducted using EFA, and the only element excluded was the actual TPACK, but two content knowledge areas were found (specific science content and general content). Also, more than eight factors have been reported in recent studies. For example, Bilici et al. (2013) reported additional contextual knowledge of the student socioeconomic status factor, and Sang et al. (2016) reported additional technological knowledge of the 
world wide web factor. For more information about most of the recent TPACK questionnaires, please see the comprehensive review of Chai et al. (2016).

Table 1

Recent studies measuring TPACK

\begin{tabular}{|c|c|c|c|}
\hline Authors & Methods used & $\alpha$ & Note of models and methods \\
\hline $\begin{array}{l}\text { Schmidt et al. } \\
\text { (2009) }\end{array}$ & PCA & $.75-.92$ & $\begin{array}{l}\text { Methods used (single factor } \\
\text { PCA), several contents in single } \\
\text { items }\end{array}$ \\
\hline Lee \& Tsai (2010) & $\begin{array}{l}\text { EFA, CFA, } \\
\text { correlation }\end{array}$ & $.92-.96$ & $\begin{array}{l}\text { 5-factor model, technological } \\
\text { specific, adapted from Schmidt } \\
\text { et al. (2009) }\end{array}$ \\
\hline $\begin{array}{l}\text { Koh, Chai, \& Tsai } \\
\text { (2010) }\end{array}$ & $\begin{array}{l}\text { EFA, correlation, } t- \\
\text { tests }\end{array}$ & $.83-.96$ & $\begin{array}{l}\text { 5-factor model, adapted from } \\
\text { Schmidt et al. (2009) }\end{array}$ \\
\hline $\begin{array}{l}\text { Chai, Koh, \& Tsai } \\
\text { (2010) }\end{array}$ & $\begin{array}{l}\text { EFA, CFA, } t \text {-tests, } \\
\text { correlation, } \\
\text { regression analysis }\end{array}$ & $.86-.99$ & $\begin{array}{l}\text { 4-factor model, adapted from } \\
\text { Schmidt et al. (2009) }\end{array}$ \\
\hline $\begin{array}{l}\text { Archambault \& } \\
\text { Barnett (2010) }\end{array}$ & EFA, correlation & $.70-.89$ & $\begin{array}{l}\text { 3-factor model, method (only } \\
\text { EFA) new instrument, } \\
\text { technological specific }\end{array}$ \\
\hline $\begin{array}{l}\text { Chai, Koh, Tsai, \& } \\
\text { Tan (2011) }\end{array}$ & $\begin{array}{l}\text { EFA, SEM (path } \\
\text { model) }\end{array}$ & $.84-.94$ & $\begin{array}{l}\text { 5-factor model, pedagogy } \\
\text { specific, based on Koh et al. } \\
\text { (2010). }\end{array}$ \\
\hline $\begin{array}{l}\text { Chai, Koh, \& Tsai } \\
\text { (2011) }\end{array}$ & EFA, CFA & $.84-.95$ & $\begin{array}{l}\text { 8-factor model, pedagogy } \\
\text { specific, based on Chai et al., } \\
\text { (2011) }\end{array}$ \\
\hline Jang \& Tsai (2012) & EFA, $t$-test, ANOVA & $.86-.96$ & $\begin{array}{l}\text { 4-factor model, technological } \\
\text { specific }\end{array}$ \\
\hline $\begin{array}{l}\text { Yurdakul et al. } \\
\text { (2012) }\end{array}$ & $\begin{array}{l}\text { Split sample EFA, } \\
\text { CFA, } t \text {-tests and test- } \\
\text { retest reliability }\end{array}$ & $.85-.95$ & $\begin{array}{l}\text { 4-factors, new instrument, } \\
\text { different factor structure }\end{array}$ \\
\hline $\begin{array}{l}\text { Koh, Chai, \& Tsai } \\
\text { (2013) }\end{array}$ & $\begin{array}{l}\text { CFA, correlation, } \\
\text { SEM path modeling. }\end{array}$ & $.89-.95$ & $\begin{array}{l}7 \text { factors but challenge of CK } \\
\text { and PCK on TPACK, based on } \\
\text { Chai et al., (2011) }\end{array}$ \\
\hline $\begin{array}{l}\text { Chai, Ng, Li, Hong, } \\
\text { \& Koh (2013) }\end{array}$ & CFA, SEM model & $.88-.92$ & $\begin{array}{l}7 \text { factors, multicultural study of } \\
\text { TPACK, cultural difference, } \\
\text { experienced teachers, based on } \\
\text { Chai et al., (2011) }\end{array}$ \\
\hline Jang \& Tsai (2013) & $\begin{array}{l}\text { PCA, } t \text {-tests. } \\
\text { ANOVA }\end{array}$ & $.89-.96$ & $\begin{array}{l}\text { Method (PCA), based on Jang \& } \\
\text { Tsai (2012) }\end{array}$ \\
\hline $\begin{array}{l}\text { Bilici Yamak, } \\
\text { Kavak, \& Guzey } \\
\text { (2013) }\end{array}$ & $\begin{array}{l}\text { PCA, CFA, } \\
\text { correlation }\end{array}$ & $.84-.94$ & $\begin{array}{l}8 \text { factors, method (PCA), strong } \\
\text { inter-correlations, new } \\
\text { instrument }\end{array}$ \\
\hline $\begin{array}{l}\text { Valtonen, Sointu, } \\
\text { Mäkitalo-Siegl \& } \\
\text { Kukkonen (2015) }\end{array}$ & $\begin{array}{l}\text { EFA, descriptive } \\
\text { statistics }\end{array}$ & $.88-.95$ & $\begin{array}{l}7 \text { factors, method (only EFA } \\
\text { used) }\end{array}$ \\
\hline $\begin{array}{l}\text { Sang, Tondeur, } \\
\text { Chai, \& Dong, } \\
\text { (2016) }\end{array}$ & EFA, CFA & $.85-.94$ & $\begin{array}{l}8 \text { factors, based on Chai, Ng et } \\
\text { al., (2011) }\end{array}$ \\
\hline
\end{tabular}

Note. EFA = exploratory factor analysis, PCA = principal component analysis, CFA = confirmatory factor analysis, SEM = structural equation modelling; TPACK = technological pedagogical content knowledge. 


\section{Purpose of the study}

Despite the challenges related to the TPACK framework, our assumption is that TPACK is a valuable tool for studying and supporting the development of pre-service teachers' twenty-first century skills. Still, developing a new instrument poses challenges from the perspective of validity. Validity is a complex, multidimensional aspect of assessment development. According to the Standards for Educational and Psychological Testing (American Educational Research Association, American Psychological Association, \& National Council on Measurement in Education, 2014): "Validity refers to the degree to which evidence and theory support the interpretations of test scores entailed by proposed uses of tests ... the process of validation involves accumulating evidence to provide a sound scientific basis for the proposed score interpretations” (p. 9). The traditional approach to evaluating validity during assessment development has followed the trinity of content validity, criterion-related validity and construct validity (Cronbach \& Meehl, 1955). Another broader approach to investigating assessment validity and reliability is to investigate factorial validity. Factorial validity refers to the evaluation of the underlying factor structure of the assessment, and evidence for this type of investigation can be supported with confirmatory factor analysis (CFA) (Brown, 2015). With CFA, a measurement instrument is evaluated by testing the fit of the hypothesised factor structure to observed data (Brown, 2015).

Following these demands, we present a study investigating the possibilities of taking the above-mentioned factors into account with the newly developed TPACK-21 measurement instrument grounded on twentyfirst century skills. The aim is to validate the TPACK-21 instrument using CFA. Previous studies have established the structure with theory, using expert review and EFA. Herein the process continues by confirming the structure as suggested by Worthington and Whittaker (2006). Also, the aim is to provide perspectives into the nature of first year pre-service teachers' TPACK based on strong and weak TPACK areas, and also to investigate the associations between latent factors and the relations of TPACK elements in the context of pre-service teachers. The main research question are:

1) How does the sample measured with TPACK-21 instrument produces the TPACK model?

2) How do the foundational elements (i.e. PK21, CK, TK) and intermediate and foundational elements (PCK21, TCK, PCK21) associate with each other and what are the pre-service teachers' strong and weak TPACK areas?

The aim is to introduce a tested instrument for measuring pre-service teachers' TPACK grounded pedagogically on twenty-first century skills (Voogt \& Roblin, 2012). The TPACK-21 instrument can be found in Appendix A.

\section{Method}

\section{Participants and procedures}

The participants included 267 first-year pre-service teachers from three universities in Finland (one annual cohort per each university). All participants will eventually graduate as certified classroom teachers (i.e., they will be certified to teach grades 1 to 6 [pupils aged 7 to 12]). The mean age of the participants was 21.7 years $(S D=3.6)$. Just over $76 \%$ of the participants were female $(n=203)$, which is representative of the Finnish classroom teacher population. Assessment data were collected as part of pre-service teacher coursework during the autumn of 2014. The study purposes and aims were explained to the participants. The respondents were not obliged to participate in the study. The data collection was conducted using an online TPACK-21 questionnaire (Appendix A).

TPACK-21 instrument was developed in phases starting from 2013. Development process began by reviewing TPACK instruments already available. Based on this review a new draft of the questionnaire was designed and the areas of twenty-first century skills (Voogt \& Roblin, 2012) were added to the areas of instrument related to the pedagogical knowledge (PK, TPK, PCK, TPACK). After this, two pilot tests were conducted, based on the results of these pilots some statements were removed, added, or changed. The initial items pool based after the review process were 86 items. In its current state, the questionnaire contains 38 statements with adequate reliability level (alpha values above .80). For More detailed information about the development process and pilot studies see Valtonen et al. (2015). According to Worthington and Whittaker (2006) new research instruments must be tested using both EFA and CFA. This paper continues 
the validation and testing process of the instrument using the CFA method in order to see how measured TPACK constructs align with the theoretical TPACK framework. Also, the aim is to publish the tested TPACK-21 instrument (Appendix A).

\section{Measure}

A self-assessment instrument called TPACK for 21st century skills (TPACK-21) (Valtonen et al., 2015) was used in this study to collect information regarding the pre-service teachers' perceptions about using technology in a pedagogically meaningful way within a twenty-first century skills framework. TPACK-21 includes seven TPACK framework areas: pedagogical knowledge (PK; 7 items), content knowledge (CK; 4 items), technology knowledge (TK; 4 items), pedagogical content knowledge (PCK; 6 items), technological pedagogical knowledge (TPK; 6 items), technological content knowledge (TCK; 4 items) and technological pedagogical content knowledge (TPACK; 7 items). Statements related to pedagogy are aligned with twenty-first century skills, this refers to PK21, TPK21, PCK21 and TPACK-21. For example, in the PK21 (Appendix A) respondents are asked to assess their knowledge related to: supporting students' reflective thinking, facilitating students' ability to make use of each other's thoughts, facilitating students' problem-solving process, and supporting students' creative thinking. Respondents assess their knowledge of TPACK areas using a 6-point Likert-type scale (1 = I need a lot of additional knowledge about the topic; $6=$ I have strong knowledge about the topic). The Cronbach's alphas in this study for TPACK-21 were for PK $(\alpha=.93)$, CK $(\alpha=.92)$, TK $(\alpha=.88)$, PCK $(\alpha=.95)$, TPK $(\alpha=.95)$, TCK $(\alpha=.89)$, TPACK $(\alpha=.96)$.

TPACK-21 was developed for (novice) pre-service teachers. Therefore, it includes scaffolding texts that briefly outline the core of each TPACK area and a short dictionary for defining the concepts. These aspects and the structure of the actual assessment instrument are intended to support its function as a reflective tool for pre-service teachers. The classroom teachers will teach several different contents of which the natural science is one of the biggest ones. For this reason, the natural science was chosen as a content knowledge for the questionnaire.

\section{Data Analysis}

Mplus v 7.11 (Muthén \& Muthén, 1998-2013) was used to fit the CFA model to the assessment data. We used weighted least squares with a mean and variance adjustments (WLSMV, robust WLS) estimator, because the item-level data were collected on a 6-point rating scale, which we considered to represent ordinal responses. As Flora and Curran (2004) suggest, WLSMV may be better suited to estimating SEM parameters for ordinal data than maximum likelihood estimation. We used the following goodness-of-fit indicators to evaluate the fit of the CFA model: chi square $\left(\chi^{2}\right)$, root mean square of the approximation (RMSEA) (Steiger \& Lind, 1980), comparative fit index (CFI) (Bentler, 1990) and Tucker-Lewis index (TLI) (Tucker \& Lewis, 1973). Because the $\chi^{2}$ indicator is incorrectly calculated in Mplus (Muthén \& Muthén, 1998-2013) and other software, we did not use it in our interpretation. Therefore, absolute indexes (RMSEA), including confidence intervals with a cut-off criterion less than 0.08 (Brown, 2015) and comparative fit indexes (CFI, TLI) with a cut-off criterion greater than 0.95 (Hu \& Bentler, 1999), were used to indicate acceptable model fit. In addition, Pearson product-moment correlations $(r)$ were computed between the latent factors. When interpreting the inter-correlations between latent factors, we used the following general criteria provide by Cohen (1988): correlations between $0.10-0.29$ were considered small, between $0.30-0.49$ moderate, between $0.50-0.69$ large and greater than 0.70 very large.

\section{Results}

CFA was used to investigate the adequacy of the hypothesised factor structure of the TPACK-21 assessment data. A graphical CFA model is presented in Figure 1. The actual TPACK factor did not fit the data (i.e., poor fit indices and multiple modification indices), and therefore it was left out of the final model. After removing the TPACK factor, the factor structure fit the data acceptably with six latent factors (CFI $=0.98$, TLI $=0.98$, RMSEA $=0.063[0.057 ; 0.069])$. 


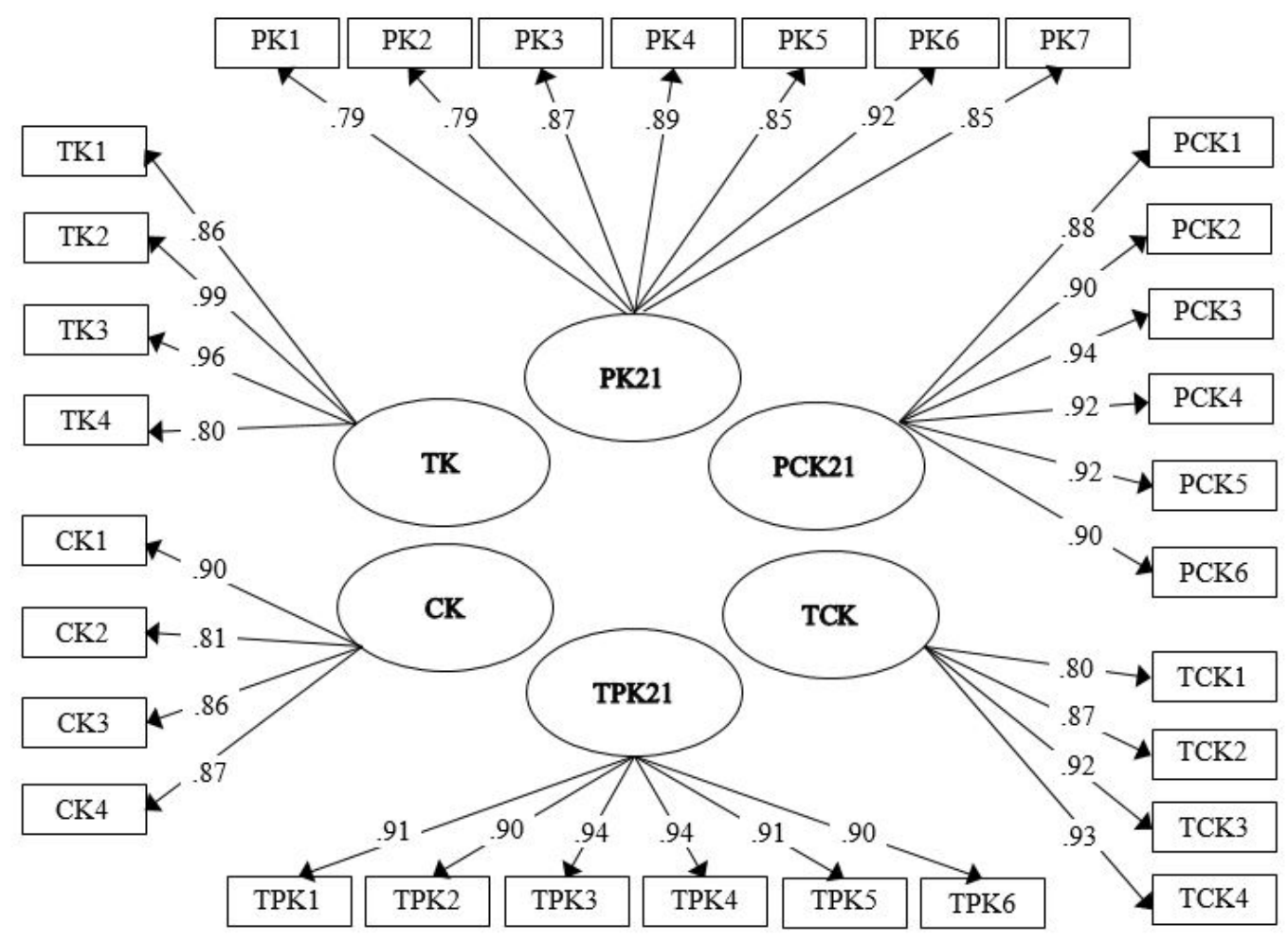

Figure 1. Confirmatory factor model of TPACK-21

$\chi_{419}^{2}=863.2, \mathrm{p}=.00, \mathrm{CFI}=.98, \mathrm{TLI}=.98, \mathrm{RMSEA}=.063[.057 ; .069]$

Note. Correlations are presented in Table 2, variances are not presented in the figure.

The TPACK-21 model CFA indicates strong individual latent factors with high loadings. As mentioned, the TPACK factor was removed from the final model. It may be that the TPACK as a construct in a latent factor model may be associated too strongly with the other factors. Thus, this may indicate that the TPACK is a latent entity of other TPACK constructs (i.e., PK, TK, CK, PCK, TCK, TPK). Correlations are not presented in Figure 1 for purposes of clarity, but these correlations as well as the means and standard deviations of the factors are presented in Table 2.

The correlations between the TPACK constructs varied from small to very large and can be found listed in Table 2. It seems that the lowest correlations were between the so-called foundational elements of TPACK21 (i.e. PK21, CK and TK). Only the correlation between CK and PK21 was stronger $(r=.47)$. The correlations were higher between all so-called intermediate elements of TPACK (i.e. PCK21, TCK, TPK21; $r=.62-.72$ ). Similarly, larger correlations were found between foundational elements and intermediate elements. These correlations align well with the assumed TPACK framework; that is, the foundational elements correlated logically with matching intermediate elements. For example, the correlations were very strong between the PCK21 and PK21 $(r=.74)$ and were large between PCK21 and CK $(r=.63)$, TCK and CK $(r=.57)$ and TPK21 and PK21 $(r=.51)$ as well as TPK21 and TK $(r=.61)$. Thus, the correlations align with the TPACK framework. Still, there are also correlations that do not follow the assumed TPACK structure very well between foundational and intermediate elements. For example, the correlations between TPK21 and CK $(r=.43)$ and TCK and PK21 $(r=.62)$ do not follow the TPACK matching as expected. 
Table 2

Correlation matrix of latent variables, means (M), and standard deviations (SD)

\begin{tabular}{|c|c|c|c|c|c|c|c|}
\hline & PK21 & TK & CK & PCK21 & TCK & $M$ & $S D$ \\
\hline PK21 & & & & & & 3.21 & 1.03 \\
\hline TK & .22 & & & & & 2.85 & 1.23 \\
\hline CK & .47 & .25 & & & & 2.98 & 1.93 \\
\hline PCK21 & .74 & .21 & .63 & & & 2.96 & 1.04 \\
\hline TCK & .48 & .44 & .57 & .62 & & 2.23 & 1.05 \\
\hline ТPK21 & .51 & .61 & .43 & .62 & .72 & 2.94 & 1.12 \\
\hline
\end{tabular}

Note. PK21 pedagogical knowledge twenty-first century skills, TK technological knowledge, CK content knowledge, PCK21 pedagogical content knowledge twenty-first century skills.

All correlations significant $\mathrm{p}<.001$. In this study, PK21, TK CK are called foundational elements of the TPACK and PCK21, TCK, TPK21 are intermediate elements of the TPACK.

The mean $(M)$ and standard deviation $(S D)$ results of novice pre-service teachers' TPACK indicate that the teachers need support for their TPACK foundational and intermediate elements. More specifically, preservice teachers' perception of their PK21 was the highest $(M=3.21, S D=1.03)$, whereas their perception of the TCK was the lowest $(M=2.23, S D=1.05)$. Generally, the technological constructs (TK, TCK and TPK21) were lower among all TPACK-21 elements. Additionally, the results indicate that no sealing effect is found with the TPACK-21 assessment instrument.

\section{Discussion}

We first investigated the TPACK-21 factor structure with CFA and then the associations between latent factors and levels of TPACK elements. The results from this study provided a six-factor model of the TPACK without the actual measured TPACK factor. In addition, the results indicated mostly logical associations between TPACK factors, which were termed foundational (i.e. PK21, CK, TK) and intermediate (PCK21, TCK, PCK21) elements (i.e., factors) of TPACK. Pre-service teachers generally felt a need for some support in all elements of the TPACK, but the technology-related areas were found to be the weakest.

The results of the TPACK-21 CFA can be viewed from two aspects: (1) from the perspective of the TPACK-21 questionnaire itself and/or (2) from the perspective of the TPACK framework. The first aspect is initially addressed in this study by the strong factorial structure that was found, indicating both factorial validity and scale reliability (e.g., Brown, 2015). However, as the validity is an ongoing process needing cumulative evidence, more research on the psychometrical aspect of the TPACK-21 is warranted in the future. Correlations between latent TPACK-21 elements aligned with the assumed TPACK framework. The moderate correlations of foundational elements indicate that PK21, CK and TK are less associated with each other as logically would be meaningful to consider. In other words, technological knowledge is something different than pedagogical knowledge, for example. The stronger correlations between intermediate elements (PCK21, TCK, TPK21) and between foundational elements and intermediate elements. These results align with the TPACK framework i.e. these areas contain overlapping areas.

The correlations between foundational and intermediate elements were moderate to large in magnitude. These results align with TPACK framework; for example, PK21 and CK correlate with PCK21. Still, the roles of content knowledge and pedagogical knowledge demand more consideration. The results indicate that the relation between PK and CK was stronger than the relation between TK and PK or CK. This result aligns with previous studies (Depaepea, Verschaffelb, \& Kelchtermansa, 2013; Segall, 2004), which indicates that pedagogical choices are content-related. Also, according to Lei (2009), pre-service teachers may have limited experiences of learning with ICT. This may also cause the stronger relation between 
PK21 and CK - that is, at the beginning of their studies, TK appears as a more separate element of TPACK. Also, the results indicate correlations that do not strictly align with the TPACK framework. CK also correlated with TPK21 even though TPK21 focuses on a combination of technology and pedagogy at a general level without content-specific features. Similarly, the correlation between PK21 and TCK was high even though TCK does not cover the pedagogical aspects of using technology in certain content areas. Generally, we assume that these results can be seen as aligning with the results of Chai et al. (2010), who indicated that pre-service teachers may have difficulties in separating the areas of TPACK from each other because of their limited studies and teaching experience. These results demand further studies focusing particularly on the development of the relations of the elements of pre-service teachers' TPACK during teacher education.

The designed instrument provides a new, pedagogically grounded tool for measuring (pre-service) teachers' knowledge how to take advantage of different technologies for supporting twenty-first century learning practices. Also, aligning with Roblyer and Doering (2010) and Doering, Veletsianos, Scharber and Miller (2009) we suggest that the TPACK framework need to be seen also as a tool for supporting (pre-service) teachers' reflective thinking. For this purpose, the instrument contains short scaffolding texts before each TPACK area aimed for outlining the core of that area and to help respondents to think and reflect better each area measured. We argue that this way the instrument can help respondents to become better aware of their strengths and development needs related to TPACK. Also, we suggest that psychometrically sound instrument with scaffolding elements serves well for the longitudinal research purposes. Currently, longitudinal studies focusing on the development of pre-service teachers' TPACK are scarce (Valtonen et al., 2015). These studies are needed in order to better outline the nature of pre-service teachers' TPACK and factors affecting the development of TPACK.

\section{Limitations and future research}

The first limitation is related to the use of one TPACK questionnaire. The results should be replicated with other TPACK assessment instruments to understand more comprehensively the TPACK theoretical framework with empirical data produced by various questionnaires. Still, this study with the TPACK-21 instrument provides an example of how to better ground TPACK instruments within certain pedagogical approaches aligning with Koh and Chai (2011). Based on these results, we assume that it is important to further develop and investigate the questionnaires used and to focus on how TPACK is empirically investigated to gain better comprehension of the nature of TPACK. The second limitation is related to the methods used in this study, namely that one confirmatory factor model was used. Thus, multiple perspectives of measurement models accompanied with item response theory (IRT) models, such as Rasch modelling, should be used. These types of studies can also answer the question of whether the TPACK model can be fitted to a single structure or whether we should consider dividing the structures based on research purposes. By better understanding the structure of TPACK, we can also assess whether there a need for measuring all elements of TPACK, including TPACK itself or a variation of the TPACK model (i.e., foundational and intermediate, in this case), or whether we could get better initial information with fewer items by using TPACK screeners - that is, measuring TPACK directly with only TPACK items. The third limitation relates to the use of correlation in the interpretation of the association between the latent constructs of TPACK. Therefore, various regression models should be used to understand the connections between the various factors of TPACK, particularly between the foundational and intermediate elements of TPACK. Moreover, longitudinal data are needed to understand the associations, and perhaps causal relations, more thoroughly in the TPACK framework. Particularly for longitudinal research, a clearer view of the foundational and intermediate aspects of TPACK is needed. Finally, as with all assessment instruments, there is a need for a continuum of psychometric investigations of the TPACK-21 questionnaire. Moreover, the mixed-methods approach using observations of actual TPACK in use among pre-service teachers should be continued. Obviously, it is important to recognise that the TPACK structure may be different among novice pre-service teachers (i.e., first year in their education) and more experienced preservice teachers (i.e., more years in pre-service teacher education and/or close to graduations) as well as between pre- and in-service teachers and that this study used data from novice pre-teachers.

Despite the limitations, in this article we have provided insight into TPACK research and have provided an example of how to develop a TPACK questionnaire grounded on twenty-first century skills. This article also provides some insights into the nature of pre-service teachers' TPACK, proposing ideas for future research. We assume that the knowledge related to the structure and development of pre-service teachers' 
TPACK grounded on twenty-first century skills provides an important starting point to support teacher education and the professional development of pre-service teachers. With psychometrically sound instruments, we are able to outline the effects that the TPACK components have on one another as well as identify the weak and strong areas that require special consideration in teacher education. Moreover, with psychometrically sound instruments, the development of TPACK can be investigated using longitudinal methods. Currently, there are studies focusing on the topic in the context of separate courses or projects specifically designed for developing teachers' TPACK (Doering et al., 2009). However, studies conducted with larger target groups following the gradual development of TPACK over longer time periods, especially in the teacher training context, are scarce (Voogt et al., 2013). Still, we assume that a longitudinal approach would be important to define the effects of teacher education and also to highlight the areas where special support is needed within teacher education.

\section{Acknowledgements}

This work was supported by the Academy of Finland (Grant numbers 296799 and 273970).

\section{References}

Ahonen, A. K., \& Kankaanranta, M. (2015). Introducing assessment tools for 21st century skills in Finland. In P. Griffin, \& E. Care (Eds.), Assessment and teaching of 21st century skills (pp. 213-225). Netherlands: Springer. https://doi.org/10.1007/978-94-017-9395-7_10

American Educational Research Association, American Psychological Association, \& National Council on Measurement in Education. (2014). Standards for educational and psychological testing. Washington, DC: American Educational Research Association.

Ananiadou, K., \& Claro, M. (2009). 21st century skills and competences for new millennium learners in OECD countries. Organisation for Economic Co-operation and Development. https://doi.org/10.1787/19939019

Archambaulta, L., \& Barnetta, J. (2010). Revisiting technological pedagogical content knowledge: exploring the TPACK framework. Computers \& Education, 55(4), 1656-1662. https://doi.org/10.1016/j.compedu.2010.07.009

Bentler, P. M. (1990). Comparative fit indexes in structural models. Psychological Bulletin, 107(2), 238246. https://doi.org/10.1037/0033-2909.107.2.238

Bilici, S. C., Yamak, H., Kavak, N., \& Guzey, S. S. (2013). Technological pedagogical content knowledge self-efficacy scale (TPACK-SeS) for Pre-service science teachers: construction, validation, and reliability. Eurasian Journal of Educational Research, 52, 37-60.

Binkley, M., Erstad, O., Herman, J., Raizen, S., Ripley, M., Miller-Ricci, M., \& Rumble, M. (2012). Defining twenty-first century skills. In P. Griffin, B. McGaw, \& E. Care (Eds.), Assessment and teaching of 21st century skills (pp. 17-66). New York, NY: Springer. https://doi.org/10.1007/978-94007-2324-5_2

Boulton-Lewis, G. (2004). Conceptions of teaching and learning at school and university: similarities, differences, relationships and contextual factors. European Journal of School Psychology, 2(1-2), 1938.

Brantley-Dias, L., \& Ertmer, P. (2013). Goldilocks and TPACK: is the construct "just right?" Journal of Research on Technology in Education, 46(2), 103-128. https://doi.org/10.1080/15391523.2013.10782615

Brown, T. A. (2015). Confirmatory factor analysis for applied research (2nd ed.). New York, NY: The Guilford Press.

Chai, C. S., Koh, J. H., \& Tsai, C.-C. (2010). Facilitating preservice teachers' development of technological, pedagogical, and content knowledge (TPACK). Educational Technology \& Society, 13(4), 63-73.

Chai, C. S., Koh, J. H. \& Tsai, C.-C. (2011). Exploring the factor structure of the constructs of technological, pedagogical, content knowledge (TPACK). The Asia-Pasific Education Researcher, 20(3), 607-615. Retrieved from http://hdl.handle.net/10497/4790

Chai, C. S., Koh, J. H., \& Tsai, C.-C. (2016). Review of the quantitative measures of technological pedagogical content knowledge (TPACK). In M. C. Herring, M. J. Koehler \& P. Mishra, (Eds.), Handbook of technological pedagogical content knowledge (TPACK) for educators (2nd ed). New York, NY: Taylor \& Francis. 
Chai, C. S., Koh, J. H., Tsai, C.-C., \& Tan, L. (2011). Modeling primary school pre-service teachers' technological pedagogical content knowledge (TPACK) for meaningful learning with information and communication technology (ICT). Computers \& Education, 57(1), 1184-1193. https://doi.org/10.1016/j.compedu.2011.01.007

Chai, C. S., Ng, E. M. W., Li, W., Hong, H. Y., \& Koh, J. H. (2013). Validating and modelling technological pedagogical content knowledge framework among Asian preservice teachers. Australasian Journal of Educational Technology, 29(1), 41-53. https://doi.org/10.14742/ajet.174

Cohen, J. (1988). Statistical power analysis for the behavioral sciences (2nd ed.). Hillsdale, NY: Lawrence Erlbaum.

Cronbach, L. J., \& Meehl, P. E. (1955). Construct validity in psychological tests. Psychological Bulletin, 52(4), 281-302. https://doi.org/10.1037/h0040957

Depaepea F., Verschaffelb, L., \& Kelchtermansa, G. (2013). Pedagogical content knowledge: a systematic review of the way in which the concept has pervaded mathematics educational research. Teaching and Teacher Education, 34, 12-25. https://doi.org/10.1016/j.tate.2013.03.001

Doering, A., Veletsianos, G., Scharber, C., \& Miller, C. (2009). Using the technological, pedagogical, and content knowledge framework to design online learning environments and professional development. Journal of Educational Computing Research, 41(3), 319-346. https://doi.org/10.2190/EC.41.3.d

Figg, C., \& Jaipal, K. (2012). TPACK-in-Practice: Developing 21st century teacher knowledge. Proceedings of Society for Information Technology \& Teacher Education International Conference, Austin, Texas, 4683-4689.

Flora, D. B., \& Curran, P. J. (2004). An empirical evaluation of alternative methods of estimation for confirmatory factor analysis with ordinal data. Psychological Methods, 9(4), 466-491. https://doi.org/10.1037/1082-989X.9.4.466

Gordon, J., Halasz, G., Krawczyk, M., Leney, T., Michel, A., Pepper, D., \& Wiśniewski, J. (2009). Key competences in Europe. Opening doors for lifelong learning (No. 87). Warsaw: CASE - Center for Social and Economic Research. https://doi.org/10.2139/ssrn.1517804

Honey, M., Fasca, C., Gersick, A., Mandinach, E., \& Sinha, S. (2005). Assessment of 21st century skills: The current landscape. New York, NY: Partnership for 21st century skills.

Hu, L., \& Bentler, P. M. (1999). Cutoff criteria for fit indexes in covariance structure analysis: Conventional criteria versus new alternatives. Structural Equation Modeling, 6(1), 1-55. https://doi.org/10.1080/10705519909540118

Jang, S. J., \& Tsai, M. F. (2012). Exploring the TPACK of Taiwanese elementary mathematics and science teachers with respect to use of interactive whiteboards. Computers \& Education, 59(2), 327338. https://doi.org/10.1016/j.compedu.2012.02.003

Jang, S. J., \& Tsai, M. F. (2013). Exploring the TPACK of Taiwanese secondary school science teachers using a new contextualized TPACK model. Australasian Journal of Educational Technology, 29(4). https://doi.org/10.14742/ajet.282

Jonassen, D., Peck, K., \& Wilson, B. (1999). Learning with technology: a constructivist perspective. Upper Saddle River, NJ: Prentice Hall.

Kember, D. (1997). A reconceptualisation of the research into university academics' conceptions of teaching. Learning and Instruction, 7(3), 255-285. https://doi.org/10.1016/S0959-4752(96)00028-X

Kereluik, K., Mishra, P., Fahnoe, C., \& Terry, L. (2013). What knowledge is of most worth: Teacher knowledge for 21st century learning. Journal of Digital Learning in Teacher Education, 29(4), 127140. https://doi.org/10.1080/21532974.2013.10784716

Koehler, M. J., Mishra, P., Bouck, E. C., DeSchryver, M., Kereluik, K., Shin, T. S., \& Wolf, L. G. (2011). Deep-play: Developing TPACK for 21st century teachers. International Journal of Learning Technology, 6(2), 146-163. https://doi.org/10.1504/IJLT.2011.042646

Koehler, M. J., Mishra, P., \& Cain, W. (2013). What is technological pedagogical content (TPACK)? Journal of Education, 193(3), 13-19.

Koh, J. H., \& Chai, C. S. (2011). Modeling pre-service teachers' technological pedagogical content knowledge (TPACK) perceptions: The influence of demographic factors and TPACK constructs. In G. Williams, P. Statham, N. Brown, \& B. Cleland (Eds.), Changing demands, changing directions. (pp. 735-746). Hobart: ascilite

Koh, J. H., Chai, C. S., \& Tsai, C. C. (2010). Examining the technological pedagogical content knowledge of Singapore preservice teachers with a large-scale survey. Journal of Computer Assisted Learning, 26(6), 563-573. https://doi.org/10.1111/j.1365-2729.2010.00372.x 
Koh, J. H., Chai, C. S., \& Tsai, C. C. (2013). Examining practicing teachers' perceptions of technological pedagogical content knowledge (TPACK) pathways: A structural equation modeling approach. Instructional Science, 41(4), 793-809. https://doi.org/10.1007/s11251-012-9249-y

Kontkanen, S., Dillon, P., Kärkkäinen, S., Kukkonen, J., Valtonen, T., \& Väisänen, P. (2015). A Second Life experiment in sex education with pre-service teachers and its contribution to the development of their proto-professional knowledge. Journal of Educational Enquiry, 14(3), 17-36.

Landry, G. (2010). Creating and validating an instrument to measure middle school mathematics teachers' technological pedagogical content knowledge (TPACK) (Unpublished doctoral dissertation). University of Tennessee, Tennessee.

Lee, M., \& Tsai, C. (2010). Exploring teachers' perceived self-efficacy and technological pedagogical content knowledge with respect to educational use of the world wide web. Instructional Science, 38(1), 1-21. https://doi.org/10.1007/s11251-008-9075-4

Lei, J. (2009). Digital natives as preservice teachers: What technology preparation is needed? Journal of Computing in Teacher Education, 25(3), 87-97. http://dx.doi.org/10.1080/10402454.2009.10784615

Lyublinskaya, I., \& Tournaki, N. (2014). Preparing special education teachers for teaching mathematics and science with technology by integrating the TPACK framework into the curriculum: A study of teachers' surveys and lesson plans. In M. Searson \& M. Ochoa (Eds.), Proceedings of the Society for Information Technology \& Teacher Education International Conference 2014 (pp. 2574-2579). Chesapeake, VA: Association for the Advancement of Computing in Education.

Mishra, P., \& Kereluik, K. (2011). What 21st century learning? A review and a synthesis. In M. Koehler \& P. Mishra (Eds.), Proceedings of Society for Information Technology \& Teacher Education International Conference 2011 (pp. 3301-3312). Chesapeake, VA: Association for the Advancement of Computing in Education.

Mishra, P., Koehler, M. J., \& Henriksen, D. (2010). The 7 transdisciplinary habits of mind: Extending the TPACK framework towards 21st century learning. Educational Technology, 51(2), 22-28.

Mishra, P. \& Mehta, R. (2017). What we educators get wrong about 21st-century learning: Results of a survey. Journal of Digital Learning in Teacher Education, 33(1), 6-19. https://doi.org/10.1080/21532974.2016.1242392

Murgatroyd, S. (2010). 'Wicked problems' and the work of the school. European Journal of Education, 45(2), 259-279. https://doi.org/10.1111/j.1465-3435.2010.01428.x

Muthén, L. K., \& Muthén, B. O. (1998-2013). Mplus user's guide (Seventh edition). Los Angeles, CA: Author.

P21Skills. (2013). 21st century student outcomes and support systems. Retrieved from: http://www.p21.org/route21/index.php

Roblyer, M. D., \& Doering, A. H. (2010). Theory and practice: foundations for effective technology integration. In K.V. Canton (Ed.), Integrating educational technology into teaching (5th ed.), Boston, MA: Allyn and Bacon.

Rotherham, A.J., \& Willingham, D. (2009). 21st century skills: the challenges ahead. Educational Leadership, 67(1), 16-21.

Sang, G., Tondeur, J., Chai, C. S., \& Dong, Y. (2016). Validation and profile of Chinese pre-service teachers' technological pedagogical content knowledge scale. Asia-Pacific Journal of Teacher Education, 44(1), 49-65. https://doi.org/10.1080/1359866X.2014.960800

Scardamalia, M., Bransford, J., Kozma, B., \& Quellmalz, E. (2012). New assessments and environments for knowledge building. In P. Griffin, B. McGaw, \& E. Care (Eds.), Assessment and teaching of 21st century skills (pp. 231-300). New York: Springer. https://doi.org/10.1007/978-94-007-2324-5_5

Schmidt, D., Baran, E., Thompson, A., Mishra, P., Koehler, M., \& Shin, T. (2009). Technological pedagogical content knowledge (TPACK): The development and validation of an assessment instrument for preservice teachers. Journal of Research on Technology in Education, 42(2), 123-149. https://doi.org/10.1080/15391523.2009.10782544

Segall, A. (2004). Revisiting pedagogical content knowledge: the pedagogy of content/the content of pedagogy. Teaching and Teacher Education, 20(5), 489-504. https://doi.org/10.1016/j.tate.2004.04.006

Shulman, L. (1986). Those who understand: Knowledge growth in teaching. Educational Researcher, 15(2), 4-14. https://doi.org/10.3102/0013189X015002004

Shulman, L. (1987). Knowledge and teaching: foundations of the new reform. Harvard Educational Review, 57(1), 1-21. https://doi.org/10.17763/haer.57.1.j463w79r56455411

Silva, E. (2009). Measuring skills for 21st-century learning. Phi Delta Kappan, 90(9), 630-634. https://doi.org/10.1177/003172170909000905 
Soh, T. M. T., Osman, K., \& Arsad, N. M. (2012). M-21CSI: A validated 21st century skills instrument for secondary science students. Asian Social Science, 8(16), 38-44.

Sointu, E.T., Valtonen, T., Kukkonen, J., Kärkkäinen, S., Koskela, T., Pöntinen, S., ... \& Mäkitalo-Siegl, K. (2016). Quasi-experimental study for enhancing pre-service teachers' TPACK. Proceedings of the Society for Information Technology \& Teacher Education international conference (pp. 3067-3074). Savannah, GA. Chesapeake, VA: AACE.

Steiger, J. H., \& Lind, J. C. (1980, May). Statistically based tests for the number of common factors. Paper presented at the Annual Meeting of the Psychometric Society, Iowa City, IA.

Tucker, L., \& Lewis, C. (1973). A reliability coefficient for maximum likelihood factor analysis. Psychometrika, 38(1), 1-10. https://doi.org/10.1007/BF02291170

Valtonen, T., Kontkanen, S., Dillon, P., Kukkonen, J., \& Väisänen, P. (2014). Finnish upper secondary and vocational level teachers at social software. Education and Information Technologies, 19(4), 763779. https://doi.org/10.1007/s10639-013-9252-1

Valtonen, T., Sointu, E., Mäkitalo-Siegl, K., \& Kukkonen., J. (2015). Developing a TPACK measurement instrument for 21st century pre-service teachers. Seminar.Net., 11(2), 87-100.

Voogt, J., Fisser, P., Roblin, N., Tondeur, J., \& Braakt, J. (2013). Technological pedagogical content knowledge - A review of the literature. Journal of Computer Assisted Learning, 29(2), 109-121. https://doi.org/10.1111/j.1365-2729.2012.00487.x

Voogt, J., \& Roblin, N. P. (2012). A comparative analysis of international frameworks for 21st century competences: implications for national curriculum policies. Journal of Curriculum Studies, 44(3), 299-321. https://doi.org/10.1080/00220272.2012.668938

Worthington, R. L., \& Whittaker, T. A. (2006). Scale development research: A content analysis and recommendations for best practices. The Counseling Psychologist, 34(6), 806-838. https://doi.org/10.1177/0011000006288127

Yurdakul, I. K., Odabasi, H. F., Kilicer, K., Coklar, A. N., Birinci, G., \& Kurt, A. A. (2012). The development, validity and reliability of TPACK-deep: A technological pedagogical content knowledge scale. Computers \& Education, 58(3), 964-977. https://doi.org/10.1016/j.compedu.2011.10.012

Corresponding author: Teemu Valtonen, teemu.valtonen@uef.fi

Australasian Journal of Educational Technology (c) 2017.

Please cite as: Valtonen, T., Sointu, W., Kukkonen, J., Kontkanen, S., Lambert, M., \& Mäkitalo-Siegl, K. (2017). TPACK updated to measure pre-service teachers' twenty-first century skills. Australasian Journal of Educational Technology, 33(3), 15-31. https://doi.org/10.14742/ajet.3518 


\section{Appendix A}

\section{Technological pedagogical content knowledge for twenty-first century skillss (TPACK-21) questionnaire}

\section{Some definitions}

- Reflective thinking - ability to consciously think about one's own studying, learning and skills

- Problem solving - ability to solve previously unknown tasks and problems by deduction and by combining previous information and experiences in a new way

- Creative thinking - ability to make use of one's own skills and to combine different sources of information in order to create something new

- Critical thinking - ability to process large amounts of information, to evaluate the reliability of information and to compare different sources of information

- Information and communications technology (ICT) - a wide arrange of different devices, such as computers, tablets, smart phones, etc., as well as web-based applications and software, social media services (e.g. blogs, Facebook, YouTube, WhatsApp, Instagram) and online learning environments (e.g. Moodle, Office365)

Scale used:

1. I need a lot of additional knowledge about the topic

2. I need some additional knowledge about the topic

3. I need a little additional knowledge about the topic

4. I have some knowledge about the topic

5. I have good knowledge about the topic

6. I have strong knowledge about the topic

\section{Pedagogical knowledge (PK)}

First, think how well you believe you know the processes of learning on a general level. Also consider in which areas you feel you need more information and in which areas you feel your current knowledge is sufficient or strong.

Evaluate your knowledge about the given topics:

PK1: Guiding students’ discussions during group work (2-5 students)

PK2: Supporting students' critical thinking

PK3: Guiding students in planning their own learning

PK4: Supporting students' reflective thinking

PK5: Guiding students to make use of each other's thoughts and ideas during group work (2-5

students)

PK6: Supporting students’ problem-solving skills

PK7: Supporting students' creative thinking

\section{Technological knowledge (TK)}

Next, consider your own relationship with information and communications technology (ICT). How do you perceive your knowledge and your skills?

Evaluate your knowledge and skills in the given topics:

TK1: I can solve ICT related problems

TK2: I am familiar with new technologies and their features

TK3: I can use new technologies

TK4: I know several websites about new technology

\section{Content knowledge (CK)}


(Note: The CK in this TPACK-21 questionnaire is always content specific, i.e., sciences in this case, but it can be changed for other contents, e.g., mathematics, languages, physical education.)

Next think about your content expertise in natural sciences (biology, geography, physics, chemistry and health). Please consider how well you believe you know the subject contents and in which areas you feel you need additional information or in which areas you feel your knowledge is sufficient or strong.

Evaluate your knowledge in the given topics:

CK1: I have sufficient knowledge in developing contents in natural sciences

CK2: I know the basic theories and concepts of natural sciences

CK3: I know the history and development of important theories in natural sciences

CK4: I am familiar with recent research in natural sciences

\section{Interaction between pedagogical and content knowledge (PCK)}

Now consider your pedagogical knowledge in natural sciences together. Please consider in which areas you feel you need additional information or in which areas you feel your knowledge is sufficient or strong.

Evaluate your knowledge about the given topics:

PCK1: In natural sciences, I know how to guide students' content-related problem solving in groups (2-5 students)

PCK2: In natural sciences, I know how to guide students' critical thinking

PCK3: In natural sciences, I know how to guide students to make use of each other's thoughts and ideas in group work (2-5 students)

PCK4: In natural sciences, I know how to guide students' reflective thinking

PCK5: In natural sciences, I know how to guide students in planning their own learning

PCK6: In natural sciences, I know how to guide students’ creative thinking

\section{Interaction between technological and pedagogical knowledge (TPK)}

Next we consider the possibilities of using ICT in teaching. First think on a general level about how well you are familiar with using technology to realise your pedagogical goals. Please consider in which areas you feel you need additional information or in which areas you feel your knowledge is sufficient or strong.

Evaluate your knowledge about the given topics:

TPK1: I know how to use ICT in teaching as a tool for students' reflective thinking

TPK2: I know how to use ICT in teaching as a tool for students to plan their own learning

TPK3: I know how to use ICT in teaching as a tool for sharing ideas and thinking together

TPK4: I know how to use ICT in teaching as a tool for students' creative thinking

TPK5: I know how to use ICT in teaching as a tool for students' problem solving in groups (2-5 students)

TPK6: I know how to use ICT in teaching as a tool for students’ critical thinking

\section{Interaction between content and technological knowledge (TCK)}

Please consider now, how well you know the technologies that are used in professions related to natural sciences.

Evaluate your knowledge about the given topics:

TCK1: I know websites with online materials for studying natural sciences

TCK2: I know ICT-applications which are used by professionals in natural sciences 
TCK3: I know ICT-applications which I can use to better understand the contents of natural sciences TCK4: I know technologies which I can use to illustrate difficult contents in natural sciences

\section{Interaction between pedagogical, technological, and content knowledge (TPACK)}

(Note. The items TPACK1-TPACK7 were not used in the analysis of this study. However, they are part of this questionnaire and thus reported here in this appendix. TPACK factor internal consistency with the current data is strong, Cronbach's $\alpha=0.96$.)

Now we add all the segments together. Please consider your pedagogical, technological and content knowledge in natural sciences together. Please consider in which areas you feel you need additional information or in which areas you feel your knowledge is sufficient or strong.

Evaluate your knowledge about the given topics:

TPACK1: In teaching natural sciences, I know how to use ICT as a tool for sharing ideas and thinking together

TPACK2: In teaching natural sciences, I know how to use ICT as a tool for students' reflective thinking

TPACK3: In teaching natural sciences, I know how to use ICT as a tool for students to plan their own learning

TPACK4: In teaching natural sciences, I know how to use ICT as a tool for students' problem solving in groups (2-5 students)

TPACK5: In teaching natural sciences, I know how to use ICT as a tool for students' creative thinking

TPACK6: In teaching natural sciences, I know how to use ICT as a tool in group work (2-5 students) TPACK7: In teaching natural sciences, I know how to use ICT in teaching as a tool for students' critical thinking 